Nina Dziatzko

German Graduate School

of Management and Law

nina.dziatzko@polymundo.de

\section{Franziska Struve}

German Graduate School

of Management and Law

\title{
Christopher Stehr
}

German Graduate School

of Management and Law

\section{Global Leadership: How to Lead Multicultural Teams Effectively?}

\begin{abstract}
Global leadership is a buzz word in today's business world. It is not clearly defined however who global leaders are: Do they work abroad or with people from different nationalities? Are they themselves living abroad or having a cross-cultural background? Are they leading virtual or non-virtual teams? Do global leaders exist or is not every leader a global leader in today's world? The following article gives a definition of global leadership and compares it with other leadership profiles: local, expat and glocal leadership. Another challenge about global leadership are the expectations towards this group of people: their expertise, skills and personality.Global leaders seem to be the answer to many questions of our globalised world. This paper describes the challenges global leaders encounter and the competencies they are supposed to dispose of. Interviews with global leaders and their teams show the way they deal with those challenges in practice.Finally, the results of the interviews help the leader discovering new opportunities to develop himself towards an inspiring global leader.
\end{abstract}


Key words: leadership, global leadership, multicultural team, diversity, interviews.

Note: all the quotations have been translated into English by the authors to facilitate the readibility of the article. The quotations in the original language can be found in the footnotes.

\section{Introduction}

Recent research focuses on the impact of multicultural teams and virtual teams on creativity and efficiency. The role of the leadership of those teams, however, is often neglected. This paper aims togive global leaders a self-reflection tool in order to assess where they position their progress towards becoming a more efficient global leader. This tool also aims to give global leaders strategies to facethe challenges they encounter (Leung, An, Tan, 2014).

Although internationalisation began with expatriation of experts to a foreign country, it is much more today. The opening of the European boarders has facilitated migration - more or less temporary or definitive - of qualified personnel (Withol de Wenden, 2013). Nowadays, increasing number ofrecent graduatesalready have either studied or worked abroad (Bolten, 2007). Furthermore, the anglo-saxon way of working has a significant impact in other regions of the world, be it through corporate culture or through educational programs like MBAs (Massol et al., 2010).

Even though the global leader is often responsible for his own integration in a foreign country, it can also be his role to assume the responsibility of assembling his staff as well. Team work, like work abroad, is a necessity as the tasks in businessbecome more and more complex (Podsiadlowski, 2002; Rosenstiel (von)/Comelli, 2003). As globalisation leads to a great diversity in the working population, it can be seen as cause and effect simultaneously (Scheffer, Werner, 2012). Leaders can be seen as product of globalisation and as driver of globalisation, accompanying a change in mindset in the business world (Osland, 2017).

This leads us to the following research questions:

1) What is global leadership? 
2) What are the challenges global leaders are facing?

3) What are solutions for global leaders to cope with potential challenges? The follwing paper focuses on global leadership. In today's globalised world global leadership seems to be the description of every kind of leadership across the globe. However, the reality is different. Becoming a successful global leader requires hard workand a high degree of self-reflection. The checklist presented in this paper is based on the result of a two-year study of MCTs (MultiCultural Teams) of software developers in the automotive sector. The checklist can be of interest for every global leader regardless of sector.

\section{Current state of knowledge}

It is difficult to define Global Leadership (an overview is given in Mendenhall et al., 2012). Reiche et al. (2016) distinguish between four types of global leaders according to the complexity of tasks and relationships in their function. Forthomme (2014) puts the focus on the fact that global leadership can only grow in the right environment, giving the organisations the responsibility to foster diversity and a global mindset. Zenger, Folkman, Evans (2014) give insights on how organisations can build up global competence).

Our understanding of global leadership is best described by Ghemawat (2012): it needs working experience abroad in order to foster the committment towards and the identification with the foreign culture. Beechler and Baltzley (2008) differentiate between global and domestic leaders. The domestic leader is comparable to the local leader mentioned below (see Figure 1.). Based on the findings of Story et al. (2014) and the figure on global mindset of Hruby (2013, p. 48), the authors distinguish between four profiles of leaders, depending on the international background (cross-culturality) of the leader and his team (see Figure 1.): 
Figure 1. Four leadership types

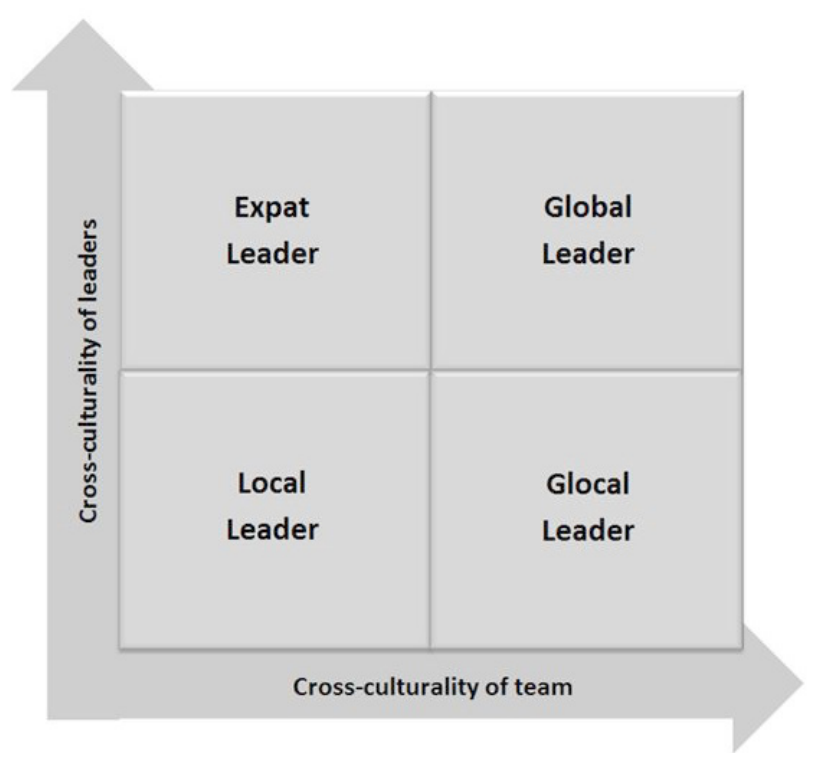

Source: own work.

- Local Leader: this leader has no intercultural profile, meaning he has not yet lived and worked abroad and leads a team of people having the same cultural background ashimself;

- Expat Leader: this leader has an intercultural profile, meaning he is currently working abroad, but his team is composed of local staff;

- Glocal leader : this leader has no intercultural profile, but leads a multicultural team. This gives him the opportunity to get initial exposure to a foreign culture even though he has never lived nor worked abroad;

- Global leader: this leader has an intercultural profile, meaning he is currently working abroad and leading a multicultural team.

Figure 1. provides a snap-shot of the current evaluation of the leaders and their teams. The authors will suggest potential development strategies depending on this initial evaluation at the end of this paper. Another point that cannot be considered in the figure is the role of the organisationalready mentioned above. Although it plays an important role, this factor will 
not be considered in depth in this article. After having defined the leader's and his team's profile, it is interesting to look at different intercultural ${ }^{1}$ leadership styles. According to Kühlmann and Dowling there are four possible strategies for leading MCTs:

1) The "dominance strategy" implies a highly autocratic style and the interest to defend one's own ideas without taking into consideration the team members' opinions. This strategy is particularly adapted to people familiar with working within a strong hierarchy. This might be related to the team member's cultural background.

2) With the "adaptation strategy" the team leader adapts his leadership style to the team's needs. This is very efficient for a team working very autonomously, but might be difficult for a team previously working within an autocratic structure in which guidance and direction are readily provided such as the "dominance strategy".

3) The "strategy of compromise" is a combination of 1. and 2.

4) The "integration strategy" puts every team member on the same level and has the objective to take everyone into consideration without privileging particular members. The choice of the strategy might depend on the tasks and competences of the team (Kühlmann, Dowling, 2004, p. 934).

All four strategies might be helpful depending on the context in which they are applied in. The choice of one of the approaches might be driven by the cultural background of the leader or his team, as suggested by Kühlmann and Dowling (2004). The global leaders interviewed for this article chose the third leadership style and this led to different reactions from the team.In general, it is helpful to be aware that different cultures may have different approaches to hierarchy and power (Hofstede, 1993). Having this awareness is part of developing intercultural competence (Lüsebrink, 2012). This competence can

\footnotetext{
1. Being originally from a German speaking background where the term "interkulturell" is widely spread, the authors prefer using the English term „intercultural“ rather than „cross-cultural”. When using the expression "cross-cultural", we use it as synonym to „intercultural".
} 
be developed during an expatriation ${ }^{2}$ or from previous experience leading MCTs (Dziatzko, 2016). Global leaders cannot content themselves with having "Classroom training" (Bird et al., 2016, p. 353) as it is not sufficient to develop those capacities. The global leaders should face situations where they are inclined to go through the phases of cultural sensitivity (Bennett, 2014) ${ }^{3}$. The awareness needed to build up this competence is not only important for the team leader, but also for his team members. The authorsconsider intercultural awareness to be passive knowledge made visible through the active knowledge of intercultural competence.

According to Bolten (2002) intercultural competence can be adopted on three levels :

1) on the behaviour level,

2) on the communication level (verbal and non-verbal) and

3) on the level of comprehension and interpretation of signs (which can be different from a country to another).

Deal and Kennedy (1982) as well as Dubar (1996) hold the opinion that a leader can more easily adapt to his environment - and by this means guarantee the company's success - by being conscious of his own culture and of his socialisation having a direct impact on his behaviour. While Pinter (2013, p. 20) no longer speaks about „expatriates", but about „flexpatriates": meaning expatriates having shorter and more frequent stays abroad, Ghemawat (2012) brings in the term "rooted cosmopolitans": global leaders being able to perform, because they are locally rooted within their own culture of origin.

Although the present article focuses on global leaders, the role of MCTs, as shown in figure 1 (cross-culturality of the team), is also relevant. The rapid globalisation and the lack of experts in some areas lead to an increase in recruiting employees with a diverse cultural background and foster the creation of MCTs (Ghemawat, 2012). In this paper, we consider that MCTs

2. Limited stay abroad for working purposes.

3. The model of cultural sensitivity, called DMIS, will be referred to in the part on culture. 
are a reality in most organisations and the global leaders have to cope with these teams. According to Dziatzko MCTs are :

„(...) a group of employees of more than two people from two different nationalities with a feeling of belonging to each other, having common norms and being in direct interaction and taking over mutual responsibility in order to reach a common target" (Dziatzko, 2016, p. 136) 4

This definition does not cover virtual teams, as first, "direct interaction” implies direct personal contact and second,virtual teams can also be composed of people only from one nationality. However, there are researchers who consider multicultural and virtual teams as being synonymous (Ghemawat, 2012).

This part summarized the profiles of global leaders, the strategies they can use to lead MCTs and the importance of cross-cultural awareness and competence. In the next part the authors will emphasize the challenges global leaders encounter and which concrete competencies can help them to cope with these challenges.

\section{Which challenges do Global leaders face?}

Although there is an awareness that cross-cultural issues play an important role in a globalised world, there is, still todayroom for improvement when it comes to the selection of adequate candidates for positions of global leadership (Frank, 2009).

The results shown in this paper do not clearly state whether or not technical skills are necessary for a global leader, however it is seen as an important competence, at least in the automotive sector. According to the interviews, there still seems to be a gap in highly qualified fields like software engineering between hard and soft skills mentioned and the impact on the company's success (Peters, Waterman, 1984).

4." (...) un groupe d'employés de plus de deux personnes de plus de deux nationalités avec un sentiment d'appartenance ayant der normes communes et se trouvant en interaction directe et se responsabilisant mutuellement afin d'atteindre un objectif commun ». 
Another study shows that a lack of cross-cultural competence is the main reason for the failure of international cooperation and expatriation (Uehlinger, 2009). Uehlinger (2009)suggests thus to further enhance social skills instead of focusing on hard facts. Nevertheless, most companies work with measurable short-term targets (Peters, Waterman, 1984).

For a global leader it is not only relevant to assess and develop his own intercultural competence (Mendenhall et al., 2017), but also to be aware of the process of team dynamics (Tuckman, 1965), especially in a cross-cultural environment.

Further expectations towards global leaders are having skills as presenter, mediator and conciliator (Jedrzejczyk, 2007) as well as decisiveness and, according to the interview results, dispose of technical skills in their area of competence. According to Bugari it is also their responsibility to create an atmosphere in which cross-culturality can be developed:

"The managers are responsible to create an atmosphere favourable to cross-culturality in which (cultural) diversity can be managed in a positive way and be seen as competitive advantage and in which the employees feel invited to invest themselves day to day for an efficient cooperation beyond cultural borders" (Bugari, 2009, p. 227)

Bugari points out the manager's responsibility as representative of the overall organisation. Empathy and recognition are important factors for motivation, and not only important in a cross-cultural context (Lesaulnier, 2013). The following table (table 1.) shows a non-exhaustive list of competencies which are particularly relevant for global leaders:

5. „Kulturell geht es für Führungskräfte darum, in ihrer Firma eine Atmosphäre zu schaffen, in der ein positiver Umgang mit (kultureller) Vielfalt als Wettbewerbsvorteil wahrgenommen wird und in der sich die Mitarbeitenden eingeladen fühlen, sich täglich für eine wirkungsvolle Zusammenarbeit über kulturelle Grenzen hinweg einzusetzen". 
Table 1. Competencies of global managers

\begin{tabular}{|l|l|l|}
\hline Professional competence & Social competence & Method competence \\
\hline Intercultural Knowledge & $\begin{array}{l}\text { Intercultural sensitivity } \\
\text { (Empathy and respectful } \\
\text { behaviour) }\end{array}$ & Language \\
\hline Technical skills & Openness & Communication skills \\
\hline Organisational knowledge & $\begin{array}{l}\text { Flexibility, practical intelli- } \\
\text { gence (ability to adapt) }\end{array}$ & $\begin{array}{l}\text { Presenter, mediator, con- } \\
\text { ciliator }\end{array}$ \\
\hline $\begin{array}{l}\text { Strategic perspective, } \\
\text { focus on and understand- } \\
\text { ing of customer, spotting } \\
\text { trends, taking risks and } \\
\text { decisions }\end{array}$ & Self-assurance & \\
\hline \multirow{7}{*}{} & $\begin{array}{l}\text { Global mindset: Good } \\
\text { character, emotionally sta- } \\
\text { ble, inquisitive, motivated, } \\
\text { tolerant }\end{array}$ & \\
\cline { 2 - 2 } & $\begin{array}{l}\text { Contextual intelligence, } \\
\text { implicit/tacit intelligence }\end{array}$ & \\
\cline { 2 - 2 } & $\begin{array}{l}\text { Create team dynamics } \\
\text { and give recognition to } \\
\text { the team }\end{array}$ \\
\cline { 2 - 3 } & \\
\hline
\end{tabular}

Source: own work based on Khanna (2014); Sperber et al. (1985); Sternberg, Wagner (1986); Zenger, Folkman, Evans (2014); Hruby (2014), Jedrzejczyk (2007).

According to Khanna (2014) the global leader should have a contextual intelligence, also named implicit or tacit knowledge comparable to the intercultural awareness mentioned in the previous part (on the current state of knowledge). According to the author this would help the leader to observe differences and to better cope with them. Sperber et al. (1985) distinguish between technical and organisational knowledge. In their article "tacit knowledge and intelligence in the everyday world", published in 1986, Sternberg and Wagner describe the practical intelligence as a capacity to adapt to an environment in order to survive and to fulfillone's own needs. Zenger, Folkman

6. The authors distinguish three kinds of competences: those which represent specific knowledge in a field, those which describe the personality and those which can be used to obtain a certain result. 
and Evans (2014, p. 4) identify the following traits as being characteristic of and particularly desirable in global leaders: good character, emotional stability, inquisitiveness, motivation and tolerance. This can be sumarized as having a global mindset (Hruby, 2014). In addition to these personality characteristics (Winsborough, Hogan, 2014) found out that global leaders share common personality traits), the global leader should have specific skills: taking a strategic perspective, focusing on and understanding the customer, spotting trends, fostering an engaged team, showing a willingness to take risks and having a comprehensive knowledge and expertise (Zenger, Folkman and Evans, 2014). Comprehensive knowledge and expertise is emphasized in the interviews mentioned in the chapter on material and methods. All the works cited above mostly agree on the requirements global leaders have to fulfill (see also Hruby, 2014). The challenge for global leaders is to demonstrate all these skills simultaneously (see Table 1).

\section{Culture and its impact on global leaders' success}

Even though it is commonly accepted that in the business world many cultures, be it nationality or corporate culture, influence the day-to-day business, there is no common understanding of what the word culture means (for definitions see Hofstede, 1993; d'Iribarne, 1989; Geertz, 1973; Schein, 2004). Podsiadlowski (2002) points out the impact culture has on global cooperation. Even though it is important for global leaders to have this in mind, it is very difficult to take this always into consideration. Frank and Bauerle illustrate why this can be challenging:

"Different processes of socialisation of team members lead to different values, representation of norms, expectations and behaviour patterns which can vary strongly within a group. When the understanding of what is polite, appropriate, what a team is and what good leadership is, is not clarified in 
advance and brought to a common understanding, the multicultural team risks heavy losses of efficiency in its cooperation"(Frank and Baeuerle, 2010, p. 1) . $^{7}$

This knowledge and awareness do not only have an impact on the leadership itself, but also on the selection of team members beforehand as Frank and Bauerle point out: "Even the expectations towards qualification and working experience can vary highly from one culture to another, so that one cannot only rely on the job description and on the field of work when selecting new team members" (Frank and Baeuerle, 2010, p. 1)8.

This statement does not only make clear which difficulties can occur when selecting new team members, but also in daily work in general. If for example the team leader has defined objectives with his team without ensuring that the team members have the same understanding of these objectives, the success of the cooperation cannot be guaranteed (Shakir, Lee, 2017).

The intercultural competence can help global leaders to develop themselves from the so-called ethnocentrism towards ethnorelativism. This can be illustrated by using Bennett's model of cultural sensitivity (DMIS) (Bennett, 2014, see detailed description in Dziatzko, 2016). This process provides a way to overcome culture shock by developing cross-cultural competence (Demorgon, 2005). Global leaders who work abroad are especially vulnerable to culture shock in the foreign country in which they live (Huber, 2007). A culture shock cannot only lead to limited success in team leadership, but even to burnout (Expat-News, 2014). Bennett uses the so-called Platinum Rule to describe the behaviour adapted in an intercultural context: "Do unto others as they themselves would have done unto them" (Bennett, 1998, p. 213). This means respecting the other's identity by treating the person like

\footnotetext{
7., Unterschiedliche Sozialisierungsprozesse der Teammitglieder resultieren in verschiedenen Werten, Normvorstellungen, Erwartungen und Verhaltensmustern, die innerhalb der Gruppe stark abweichen können. Wenn das Vorverständnis dafür, was höflich, was angemessen, was überhaupt ein Team und was eine richtige Führung ist, nicht im Vorfeld ausführlich geklärt und auf einen gemeinsamen Nenner gebracht wird, drohen dem multikulturellen Team große Reibungsverluste bei der Zusammenarbeit". 8.„Auch die Anforderungen an Qualifizierung und Arbeitserfahrung können von Kultur zu Kultur stark variieren, sodass man sich bei der Auswahl der Teammitglieder nicht allein auf die Beschreibung ihrer Funktion und ihres Aufgabenbereichs verlassen kann".
} 
she would like to be treated and not to treat her like oneself would like to be treated. Knowing this can be of great value for global leaders.

Further, the development of team members is seen as a task which a successful global leader should be aware of, without neglecting his own development. Regarding the development of the team as a whole Tuckman (1965) can provide insights on evaluating the team's status (see Dziatzko, 2016).

Most of these points take time and effort, especially in a global context (Jedrzejczyk, 2007). In volatile and uncertain times, it is particularly endeavouring, but according to Beechler and Baltzley (2008) it is one part of global leadership: to dispose of a global mindset in order to be able to cope with complexity and ambiguity (Clapp-Smith, Vogelsang-Lester, 2014). If the effort is made by the global manager he is more likely to get trust from his team. Trust also fosters team identity(for more details on creating trust through the use of humour see Dziatzko, 2016). Jedrzejczyk (2007) holds the opinion that this takes more time for MCTs than for non-MCTs.

\section{Material and Methods}

The study belongs to the field of anthropology and ethnography as the main aim was to unveil the functioning of cultures (Mulder van den Graaf, 1989; Trochim, 2010). For this purpose qualitative, semi-directive interviews were conducted. The qualitative approach helps to show unconscious behaviour and hidden assumptions (Mulder van den Graaf, 1989) as well as socia interactions and symbols and rituals particularly valuable in a culture (Hofstede, 2006). As the interviews were only done by one resercher, the results might be biased (Berger, 2015). A way to cope with this bias is to see situations in a given context (Berg, 2012)

The following partpresents results of interviews done with MCTs of software developers in the automotive sector. The teams develop software for electric vehicles and racing cars. As these fields of work need very specific expertise, the competencies to fulfill the tasks cannot be covered by the 
local working market. This is the reason why people from all over the world were recruited and MCTs were created. These MCTs work in an organisation where other teams are not specifically diverse regarding cultural backgrounds. This means that the company culture was, until then, mainly focused on "monocultural teams". With this background in mind, the following results have even more significance for the organisation as a whole.

Global managers (according to the definition mentioned in the part on the current state of knowledge) and their teams were asked to describe what good leadership means for them ${ }^{9}$.

The first interviewed global leader sees himself more as a supporter. He pays attention that no employee feels isolated in the team. In order to do so, he fixes timeslots with each team member and listens to their concerns. He also tolerates and values different opinions which is an indicator fora culture allowing to learn from failure (Lenz, 2015).

It is interesting to see that he intervenesonly when his team members need it. He offers technical support, but only if necessary. This is the key to leadership for him : to be able to trust the employees as being able to do their job and at the same time showing them that he can support if needed. Cremer (de) (2015) speaks in this context about factual and relational trust by giving the example of negotiations between Germans (more enclined to build trust on facts) and Chinese (Guanxi, the in-group, will be subject to giving trust). This shows that values, although considered as being universal, can be interpreted differently in different countries (Glinkowska, 2016).

If we want to evaluate global leaders, it is not only helpful to look at how they lead and why, but also to ask their teams how they feel about their leadership. One team member appreciates his leader because he says what he thinks.

9. The selection of the research subject follows criteria fixed beforehand. In the present case the global leaders were responsible for teams:

1. Whose members were all multicultural (according to the definition in chapter 1.),

2. speaking English as working language,

3. working in an industry were the domestic market cannot provide the competence needed,

4. working in organizations with a comparable size,

5. with a low average age (about 30 years). 
Some of the team members however,feel they do not receive sufficient guidance. The feeling of the leader that he thinks he might need to supervise some of his team members more closely, seems to be right. This shows, that leadership also needs intuition. Other team members however, appreciate the freedom they get from their leader. They recognize that their team leader is open to discussion and values other opinions. He gives his team members the opportunity to show their expertise in front of the top management and at the same time he protects his team from the pressure coming from above. One team member points out that the team leader is listening to his team and provides support when problems occur. Two other team members share this opinion as well.

Another team member provided his definition of good leadership. He has been team leader in former jobs and is famliar with both leadership and followership: "Good leadership for me is by example. (...) So the good leadership is to measure what skills every team member is having now" (Dziatzko, 2016, p. 274). When speaking about his own experience as a leader he mentions the role of honesty towards the team members and the importance of giving them the feeling to work for themselves as a team and not only for the company. When asked about the current situation, he mentions that: "The management was open to any discussion, so if I have any new ideas they take it and we implement it. It's not like we are prohibited to say something" (Dziatzko, 2016, p. 274). He does not only feel that his opinionis valued, but that suggesting new ideas is encouraged.

If we look at the statement of a person who wants to be led closer it shows that he wants the manager to come towards him instead of having to ask: "Unless you go directly and ask, you don't really know what's going to happen" (Dziatzko, 2016, p.274). Three other team members feel the same about the situation.

This shows that the same behavior of the gobal leader can lead to different perceptions. In this case one half of the team appreciates the way they are led while the other half would like to be led differently. They all point 
out that they want to be more closely led by their manager. In the next part another global leader and his team's views will be compared to the statements cited above. This will help us to develop general strategies which can serve global leaders and their teams.

It is interesting to see that the leader of the second team, has an understanding of good leadership similar to his counterpart from the first team although they do not know each other and do not work in the same environment. He also mentions the importance of understanding and giving the team the freedom to work on things that matter and to make a contribution to the team.

He also focuses on strengths and skills of the team members. For this leader it is important to develop his team's potential and to support the personal development of the team members. A key element he mentions are the expectations towards the team's work: what they are able and willing to contribute. So this seems particularly relevant when working in a global context. The previous part showed that the expectations of good leadership and its implementation can be very different.

The reactions of the team members from the second team are slightly different from the answers from the first team and seem to contradict the view of their own leader. Half of the team sees him as the authority making the decisions. One third of the team mentions the importance of personal development. This point was not raised at all by the first team, but the leader of the second team seems to emphasize this, so that his team members give importance to this point as well. Like the first team, the second teamalso respectstheir leader because of his technical knowledge.

It is obvious that technical expertise is a key factor for both teams. It is clear for one intervieweethat the leader will take the decision and not his team. For the first team this point is not mentioned, but the team members seem to have more authority to take their own decisions.One team member does not necessarily see the manager as being the technical expert, but more as the expert to make the decision based on the technical information he gets from his team. It is also his responsibility to communicate them to the team. 
In fact, there seems to be a contradiction within the team regarding the viewof the leader's responsibility. Other team membersalso value the manager as decision-maker and as visionary.

\section{Results}

The previous parts showed what is important when leading global teams. Even though the results are not specific to MCTs, they are even more relevant in an international, complex and rapidly changing environment.

The survey showed that the following points are particularly relevant for global leaders:

- Recognise and use the strengths of the team members

- Be fair and prefer a transparent and trustful communication

- Elaborate a common vision with the team

- Be empathetic and listen to the team members' needs

- Defend the team's ideas towards the higher management

The points mentioned above are relevant for every leader, be it a global or a domestic one, although it is questionable to which extent domestic leadershipstill exists. Companies might be far behind the expected benefits of globalisation; however, the preception that leaders are able to act in every culture is however still prevailing(Ghemawat, 2012). The following recommendations are based on the above mentioned outcomes of the interviews:

1) Dispose of language skills in English and in the company language (if different) in order to be able to communicate appropriately.

2) Have cultural sensitivity (see Bennett, 2014), for example through working experience abroad (as global leader).

3) Be aware that the understanding of leadership might differ between countries (see Frank, Baeuerle, 2010; Biermeier-Hanson, Liu and Dickson, 2015). 


\section{Final remarks}

The following paper adressed the question how global leaders can cope with the challenges they encounter. First, the authors gave a brief definition of global leadership and multicultural teams. Second, the competencies global leaders need were highlighted and the challenges they encounter where described. Third, the interviews illustrated how global leaders and their teams cope with challenges and which competencies they value. Finally, the results were briefly presented.

The limitations of this study consist in the small number of interviewees and the concentration on one sector. For this reason it might be interesting to conduct a similar study with teams from other departments or in other sectors. Furthermore, the interviews have been conducted by one researcher and not a group of researchers which can lead to a bias. It would be valuable to conduct the interviews again in order to see the evolution they have gone through over the time.

Further research could be done on the role of the company for the success of multicultural teams. It would be of great interest to search for measures supporting the formation of multicultural teams. Some hints have already been adressed in former research, but could be explored more in depth (Dziatzko, 2016). Looking at the recruitment strategy it might be helpful to define personality traits and profiles of ideal-typic global leaders, former studies having already confirmed the positive link between cosmopolitanismand global leadership (Levy, Peiperl and Jonsen, 2016). An evaluation of the intercultural openness of the organisation could be a good starting point for establishing a diversity management strategy on an organizational level.

Another valuable contribution would be to develop a leadership training to become a global leader. This could be a "train-the-trainer" concept where former expatriates would train their peers, benefiting the company by fostering the exchange of knowledge and experience. 
The goal of this paper was to outline possible strategies for global managers to effectively lead MCTs. If the manager's values are in accordance with those of the company, he will be able to authentically communicate his expectations to the teams he is leading. 


\section{References}

Beechler, S., Baltzley, D. (2008) Creating a global mindset, in: Chief Learning Officer. June, pp. 40-45.

Bennett, M. (last revised in 2014) The Developmental Model of Intercultural Sensitivity. (Online), available: http://www.idrinstitute.org/page.asp?menu1=15, (19th July, 2017).

Bennett, M. (1998) Overcoming the Golden Rule: Sympathy and Empathy, in: M.Bennett, Milton (ed.) Basic Concepts of Intercultural Communication, Selected Readings. Boston/London: Intercultural Press, pp. 119-214.

Berg, B.L. (2012) Qualitative Research Methods for the Social Sciences. 8th edition. Boston, MA: Allyn and Bacon.

Berger, R. (2015) Now I see it, now I don't: researchers' position and reflexivity in qualitative research. Qualitative Research, vol. 15, n², 04/2015, pp. 219-234.

Biermeier-Hanson, B., Liu, M., Dickson, M.W. (2015) Alternative views of gobal leadership: applying global leadership perspectives to leading global teams, in: J.L. Wildman, R.L. Griffith, (eds.) Leading global teams. Springer Sciences+Business Media: New York, pp. 195-223.

Bird, A., Mendenhall, M., Osland, J., Oddou, G., Reiche, S. (2016) Global Leadership in Perspective. The Routledge Companion to Leadership, pp. 348-358.

Bolten J. (2002) Interkulturelle Kompetenz und ganzheitliches Lernen - Zur Theorie und Praxis interkultureller Kompetenzvermittlung in der Wirtschaft. Dokumente 5/2002, pp. 40-45. 
Bolten, J. (2007) Einführung in die - interkulturelle Wirtschaftskommunikation, Göttingen: Vandenhoeck \& Ruprecht.

Bugari, A. (2009) Interkulturelles Leadership als Unternehmenskultur: Awareness Coaching als Basis mit Messbarkeitsfaktor, in: C. Voigt (éd.), Interkulturell führen - Diversity 2.0 als Wettbewerbsvorteil. Zürich: Verlag Neue Zürcher Zeitung, pp. 215-227.

Clapp-Smith, R.; Vogelsang Lester, G. (2014) Defining the "mindset" in global mindset: modelling the dualities of global leadership. Advances in Global Leadership, vol. 8, pp. 205-228.

Cremer (de), D. (2015) Understanding Trust, In China and the West. Harvard Business Review, 11 $1^{\text {th }}$ February, 2015, (Online), available: https://hbr.org/2015/02/understandingtrust-in-china-and-the-west, (19th July, 2017).

Deal, T.E., Kennedy, A.A. (1982) Corporate cultures: the rites and rituals of corporate life. Reading, Mass: Addison-Weasley.

Demorgon, J. (2005) Pour une analyse critique de la compétence de compréhension et d'agir interculturels, in: F. Baasner (ed.), Gérer la diversité culturelle. Frankfurt am Main: Peter Lang, pp. 13-41.

Dubar C. (1996) La socialisation: construction des identités sociales et professionnelles, $2^{\text {nd }}$ ed., Paris: A. Colin.

Dziatzko, N. (2016) Les enjeux d'une coopération internationale à l'exemple d'équipe multiculturelles du BMW Group. Utz Verlag: München. 
Expat-News (2014) Kulturschock - die wirtschaftlichen Folgen für Unternehmen. Rubrik Interkulturelles. (Online), available: https://www.expat-news.com/18741/interkulturelle-kompetenzen-ausland/kulturschock-die-wirtschaftlichen-folgen-fuer-unternehmen/, (18th April, 2017).

Forthomme, P. (2014) L'équipe multiculturelle ou l'intelligence de la diversité, pp. 1-6, (Online), available: http://www.forthomme.net/uploads/docs/publication-equipe-multiculturelle.pdf, (25thFebruary, 2014).

Frank, S. (2009) Die Rollen eines internationalen Managers. Handelsblatt. $22^{\text {nd }}$ June 2009, (Online), available: http://www.handelsblatt.com/unternehmen/management/ strategie/weltspitze-die-rollen-eines-internationalen-managers-seite-all/3203642-all. htm, (2nd May 2014).

Frank, S., Baeurle, I.I. (2010) Wie Sie in internationalen Teams effektiv arbeiten. Handelsblatt. 29 ${ }^{\text {th }}$ November, 2010, (Online), available: http://www.handelsblatt. com/unternehmen/management/strategie/weltspitze-wie-sie-in-internationalen-teams-effektiv-arbeiten/3650916.html, (19th July, 2017).

Geertz, C. (1973) The interpretation of cultures: selected essays. New York, Basic Books, (Online), available: https://monoskop.org/images/5/54/Geertz_Clifford_The_Interpretation_of_Cultures_Selected_Essays.pdf, (19th July, 2017).

Ghemawat, P. (June 2012) Developing Global Leaders. Mc Kinsey Quarterly, (Online), available: http://www.mckinsey.com/global-themes/leadership/developing-global-leaders?cid=eml-web, (8th, June 2017).

Glinkowska, B. (2016) Managing Teams in the Multicultural Organizations. Journal of Intercultural Management, Vol. 8, n², June 2016, pp. 55-69. 
Hofstede, G. (2006) Lokales Denken, globales Handeln - interkulturelle Zusammenarbeit und globales Management. $3^{\text {rd }}$ ed., München: DTV.

Hofstede, G. (1993) Cultural constraints in management theories. Academy of Management Executive, vol. 7, n¹, pp. 81-94.

Hruby, J. (2014) Global Mindsets. Springer Fachmedien: Wiesbaden.

Hruby, J. (2013) Das Global Mindset von Managern. Springer Gabler: Wiesbaden.

Huber, B. (2007) Kulturschock Auslandsaufenthalt - auf Kosten der Gesundheit? Aspekte einer Auslandsentsendung und ihr Einfluss auf den Gesundheitszustand von Expatriates. (Online), available: http://www.icunet.ag/fileadmin/content/innovation/ Studie_-_Kulturschock_Auslandsaufenthalt.pdf, (27th March, 2017).

Iribarne, (d') P. (1989). La logique de I'honneur - Gestion des entreprises et traditions nationales. Paris: Editions du Seuil.

Jedrzejczyk, P. (2007) Multikulturelle Teams in Organisationen - eine experimentelle Untersuchung des Problemlöseverhaltens unter Wettbewerbsbedingungen. Schriften zur empirischen Ent-scheidungs-und Organisationsforschung, vol. 23, Frankfurt am Main et al.: Peter Lang.

Khanna, T. (2014) Intelligent expandieren. Harvard Business Manager, 11/2014, pp. 27-37.

Kühlmann, T.M., Dowling, P. (2004) Interkulturelles Personalmanagement, in: E. Gaugler, et al. (eds.), Enzyklopädie der Betriebswirtschaft Band V-Handwörterbuch des Personalwesens. $3^{\text {rd }}$ ed., Stuttgart: Schäffer-Poeschel Verlag, pp. 928-937.

Lenz, B. (2015) Failure is essential to learning, (Online), available: https://www.edutopia. org/blog/failure-essential-learning-bob-lenz, (21st July, 2017). 
Lesaulnier, F. (2013) Manager une équipe multiculturelle, (Online), available: http:// revolution-rh.com/manager-une-equipe-multiculturelle/, (19th July, 2017).

Leung, K., Ang, S., Tan, M.L. (2014) Intercultural Competence. Annual Review of Organizational Psychology and Organizational Behavior, vol. 1, n¹, pp. 489-519.

Levy, O., Peiperl, M. A.; Jonsen, K. (2016) Cosmopolitanism in a globalized world: an interdisciplinary perspective. Advances in Global Leadership, August 2016, pp. 281-323.

Lüsebrink, H.-J. (2012) Interkulturelle Kommunikation - Interaktion, Fremdwahrnehmung, Kulturstransfer. $3^{\text {rd }}$ ed., Suttgart, Weimar : Verlag J. B. Metzler.

Massol, J., Vallée, T., Koch, T. (2010) Les élites économiques sont-elles encore si différentes en France et en Allemagne? Regards sur l'économie allemande, n97, pp. 5-14, (Online), available: http://rea.revues.org/4104, (19th July, 2017).

Mendenhall, M.E., Weber, T.J., Anardottir, A.A., Oddou, G.R. (2017) Developing global leadership competencies: a process model. Advances in Global Leadership, July 2017, pp. 117-146.

Mendenhall, M.E.; Reiche, B.S.; Bird, A.; Osland, Joyce, S. (October 2012). Defining the "global" in Global Leadership. Journal of World Business, Vol. 47, Issue 4, pp. 493-503.

Mulder von de Graaf, J.; Rottenburg, R. (1989). Feldforschung im Unternehmen Ethnografische Explorationen in der eigenen Gesellschaft, in: R. Aster, H. Merkens, M. Repp, (eds.) Teilnehmende Beobachtung - Werkstattberichte und methodologische Reflexionen. Frankfurt am Main, New York: Campus Forschung, vol. 632, pp. 19-34.

Osland, J.S, Ehret, M., Ruiz, L. (2017) Case studies of global leadership: Expert cognition in the domain of large-scale global change. Advances in Global Leadership, July 2017, pp. 41-88. 
Peters, T.J.; Waterman, R.H. Jr. (1984) Auf der Suche nach Spitzenleistungen - was man von den bestgeführten US-Unternehmen lernen kann, $10^{\text {th }}$ ed., Landsberg am Lech: Verlag moderne Industrie.

Pinter, E. (2013) Von Expatriates zu Flexpatriates. TRAiNiNG, 05/2013, p. 20.

Podsiadlowski A. (2002) Multikulturelle Arbeitsgruppen in Unternehmen - Bedingungen für erfolgreiche Zusammenarbeit am Beispiel deutscher Unternehmen in Südostasien, Münchner Beiträge zur Interkulturellen Kommunikation, vol. 12, Münster: Waxmann Verlag.

Rosenstiel (von) L., Comelli, G. (2003) Führung zwischen Stabilität und Wandel. München: Verlag Franz Vahlen.

Scheffer J., Werner H. (2012) Widerstände der Vernetzung. Interkulturelle Kommunikation in virtuellen Teams am Beispiel deutsch-amerikanischer Arbeitsgruppen bei der BMW Group, in: U. Reutner (ed.), Von der digitalen zur interkulturellen Revolution. Baden-Baden: Nomos Verlag, pp. 335-348.

Schein, E.H. (2004). Organization culture and leadership. $3^{\text {rd }}$ ed., San Francisco: Jossey-Bass Publishers.

Shakir, F.Y., Lee, Y.-T. (2017) Connecting across cultures: an empirical examination of multicultural individuals as global leaders. Advances in Global Leadership, August 2017, pp. 1-40.

Sperber, W., Wölpel, S., Jäger, A.O., Pfister, R. (1985) Praktische Intelligenz. Untersuchungsbericht und erste Ergebnisse. Arbeitsbericht 5 aus dem Forschungsschwerpunkt Produktives Denken - Intelligentes Verhalten. Freie Universität Berlin. 
Sternberg, R.J., Wagner, R.K. (1986) Tacit knowledge and intelligence in the everyday world, in: Intelligence - nature and and origins of competence in the everyday world. Cambridge, New York, Melbourne: Cambridge University Press, pp. 51-83.

Story, J.S.P., Barbuto Jr. J. E., Luhans, F.,Bovaird, J.A. (2014) Meeting the Challenges of Effective International HRM: Analysis of the Antecedents of Global Mindset. Human Resource Management, 53:1, pp. 131-155.

Trochim, W.M.K. (2010). Research Methods Knowledge Base, (Online), available: https:// www.socialresearchmethods.net/kb/index.php, (15th, June 2017).

Tuckman, B.W. (1965) Development sequences in small groups. Psychological bulletin, $n^{\circ} 63$, pp. 348-399.

Uehlinger, C. (2009) Bedeutet international arbeiten interkulturell kompetent zu sein?, in: C. Voigt (ed.), Interkulturell führen - Diversity 2.0 als Wettbewerbsvorteil. Zürich: Verlag Neue Zürcher Zeitung, pp. 255-266.

Withol de Wenden, C. (2013) Crise et migrations intra-européennes. Marché européen de la main d'oeuvre ou fuite des cerveaux?, in: T. Montbrial, P. Moreau Defarges (eds.) Ramses - rapport annuel sur le système économique et les stratégies, ifri. Paris: Dunod, pp. 106-111.

Zenger, J., Folkman, J., Evans, C. (2014) Global Leadership Development-How global organisations can successfully position leaders for global expansion. White Paper. Zenger Folkman, pp. 1-8. 